\title{
MICROSTRUCTURAL CHANGES OF FINE-GRAINED CONCRETE EXPOSED TO A SULFATE ATTACK
}

\author{
MIKROSTRUKTURNE SPREMEMBE DROBNOZRNATEGA \\ BETONA, IZPOSTAVLJENEGA SULFATU
}

\author{
Martin Vyšvařil, Patrik Bayer, Markéta Rovnaníková \\ Brno University of Technology, Faculty of Civil Engineering, Institute of Chemistry, Žižkova 17, 60200 Brno, Czech Republic \\ vysvaril.m@fce.vutbr.cz
}

Prejem rokopisa - received: 2014-07-30; sprejem za objavo - accepted for publication: 2015-01-05

doi: $10.17222 /$ mit.2014.138

\begin{abstract}
Sulfate attack is one of the major threats to durability of concrete constructions and it becomes a major destructor of sewagecollection systems where concrete sewer pipes are exposed to sulfates. The most frequent biodeterioration in sewage pipes is caused by biogenic sulfuric-acid corrosion. During this attack, the $\mathrm{pH}$ of the surfaces of concrete sewer pipes is reduced and chemical reactions lead to the cracking and scaling of the concrete material, accelerated by the sewage flow. This paper is focused on the sulfate attack on fine-grained concrete where the effect of a $0.5 \%$ sulfuric-acid solution on the microstructural changes of various types of concrete after a treatment for a period of 6 months was investigated with mercury intrusion porosimetry and scanning electron microscopy. It was found that the total porosity of most samples was decreased after the sulfate attack, indicated by the products of the sulfate corrosion filling in the pores of the concrete. The smallest changes in the microstructure were observed in the samples made from sulfate-resisting cements. The formation of the locations rich in sulfur, iron and aluminum during the sulfate attack of the concrete was determined by mapping the chemical-element distribution.

Keywords: sulfate attack, porosity, microstructure, ettringite, gypsum

Izpostavitev sulfatom je ena od glavnih groženj za obstojnost betonskih struktur in postaja glavni uničevalec v sistemih zbiranja odplak, kjer so betonske cevi izpostavljene sulfatom. Najpogostejša biorazgradnja betonskih cevi za zbiranje odplak je povzročena z biogensko korozijo z žvepleno kislino. Med tem napadom se pH površine zmanjša in kemijske reakcije, pospešene s tokom odplak, povzročijo pokanje in luščenje materiala iz betona. Clanek obravnava vpliv izpostavitve sulfatov na drobnozrnat beton, kjer je bil preiskovan učinek raztopine žveplene kisline $0,5 \%$ na mikrostrukturne spremembe različnih vrst betonov po izpostavitvi 6 mesecev. Uporabljena je bila porozimetrija z vdorom živega srebra in vrstična elektronska mikroskopija. Ugotovljeno je bilo, da je bila skupna poroznost vzorcev zmanjšana po učinkovanju sulfata, kar kaže, da se pore v proizvodih napolnijo s produkti sulfatne korozije. Najmanjše spremembe mikrostrukture so bile opažene pri vzorcih izdelanih betonov, odpornih proti sulfatom. V betonu, izpostavljenem sulfatom, je bil nastanek področij, bogatih z žveplom, železom in aluminijem določen z razporeditvijo kemijskih elementov.

Ključne besede: izpostavitev sulfatom, poroznost, mikrostruktura, etringit, sadra
\end{abstract}

\section{INTRODUCTION}

Durability of concrete has become a very relevant issue in construction projects over the last decades. Sulfate attack is one of the major threats to the durability of concrete constructions and it is a major destructor in sewage-collection systems where concrete sewer pipes are exposed to sulfates. The sulfates originate from the waste water as well as from the biogenic activity of bacteria - microbiologically induced concrete corrosion $(M I C C) .{ }^{1}$ The most frequent biodeterioration in sewage pipes is caused by biogenic sulfuric-acid corrosion. ${ }^{1,2}$ During this attack, the $\mathrm{pH}$ of the surfaces of concrete sewer pipes is reduced and chemical reactions lead to the cracking and scaling of the concrete material accelerated by the sewage flow. The rate of the loss of a concrete material can be $3-6 \mathrm{~mm}$ per year, thereby the breakingout of steel reinforcement can take place, resulting in the subsequent corrosion of the steel reinforcement. ${ }^{3}$ From this aspect, a sulfate attack in the sewage system is very dangerous, especially in the areas with waste water rich in sulfates or $\mathrm{H}_{2} \mathrm{~S}$.
The formation of ettringite (AFt) from calcium sulfate (gypsum) and $\mathrm{C}_{3} \mathrm{~A}$ via monosulfate $(\mathrm{AFm})$, according to Equation (1), is the main chemical reaction of the sulfate attack on concrete. ${ }^{4}$ Gypsum is the primary product of the chemical sulfate attack on concrete (formed by the reaction of sulfate anion with calcium hydroxide):

$$
\begin{array}{lrr}
\mathrm{C}_{\bar{S}} \mathrm{H}_{2}+\mathrm{C}_{3} \mathrm{~A}+1 \mathrm{OH} & \rightarrow \mathrm{C}_{4} \mathrm{ASH}_{12} \stackrel{2 \mathrm{C} \overline{\mathrm{S}} \mathrm{H}_{2}+16 \mathrm{H}}{\longrightarrow} \underset{\text { gypsum }}{\longrightarrow} \mathrm{C}_{6} \mathrm{~A}_{3} \overline{\mathrm{S}}_{3} \mathrm{H}_{32} \\
\text { monosulfate } & \text { ettringite (1) }
\end{array}
$$

Ettringite has a relative low density $\left(1.75 \mathrm{~g} \mathrm{~cm}^{-3}\right)$ in comparison to, e.g., the C-S-H phase $\left(2.0 \mathrm{~g} \mathrm{~cm}^{-3}\right)$ and a considerably larger volume than the initial compounds, therefore its formation provides a potential stress in the hardened cement paste. ${ }^{5}$ The theoretical volume increase varies depending on the source of the available aluminum. The sources of reactive aluminum are AFm phases (monosulfate, monocarbonate) and calcium aluminate originating from the clinker phases $\left(\mathrm{C}_{3} \mathrm{~A}, \mathrm{C}_{4} \mathrm{AF}\right)$. The ettringite formation can be reduced by lowering the $\mathrm{C}_{3} \mathrm{~A}$ content in the cement. According to the European stan- 
dards EN 196 and EN 197, sulfate-resistant cements are limited in the $\mathrm{C}_{3} \mathrm{~A}$ content to $<3 \%$ and the $\mathrm{Al}_{2} \mathrm{O}_{3}$ content to $<5 \%$.

Systematic studies and reviews were done to evaluate the deterioration processes of the secondary-ettringite formation due to an external sulfate attack on hydrated cement paste, mortar and concrete. ${ }^{4,6,7}$ The results showed that the amounts of $\mathrm{C}_{3} \mathrm{~A}(0-8 \%)$ in the cement systems do not necessarily protect them from a sulfate deterioration. In contrast, the $w / c$ ratio of the investigated samples had a major impact on the failure time of the samples during 40 years of exposure under real conditions. The permeability (porosity) of concrete samples has a major influence on the deterioration of the samples. It is generally agreed that the alumino-ferrite phase $\left(\mathrm{C}_{4} \mathrm{AF}\right)$ seems to be less important with regard to the secondary-ettringite formation during a sulfate attack due to its lower reaction kinetics. ${ }^{8,9}$ The formation of secondary ettringite from $\mathrm{C}_{4} \mathrm{AF}$ in the presence of gypsum (sulfate) and the formation of aluminum- $\left(\mathrm{AH}_{3}\right)$ and iron-hydroxide $\left(\mathrm{FH}_{3}\right)$ are given in Equation (2):

$3 \mathrm{C}_{4} \mathrm{AF}+12 \mathrm{CS}_{2}+\mathrm{xH} \rightarrow 4 \mathrm{C}_{6} \mathrm{~A}_{2} \overline{\mathrm{S}}_{3} \mathrm{H}_{32}+2(\mathrm{~A}, \mathrm{~F}) \mathrm{H}_{3}$

Besides ettringite, gypsum can also form during a sulfate attack, especially in highly concentrated sulfate solutions. ${ }^{10,11}$ The influence of a gypsum formation on the performance of cement pastes, mortars and concretes was studied in detail by many authors. ${ }^{6,12-14}$ It was suggested that the secondary-gypsum formation is related to the amount of alite $\left(\mathrm{C}_{3} \mathrm{~S}\right)$ in the cement system due to the possibility of a portlandite formation. The transformation of portlandite into gypsum can cause an expansion, usually later, during the sulfate exposure, and the softening of the near-surface regions due to the gypsum formation was also observed. The softening was attributed to the decalcification of the C-S-H phase.

At lower temperatures, thaumasite $\left(\mathrm{CaSiO}_{3} \cdot \mathrm{CaSO}_{4}\right.$. $\left.\mathrm{CaCO}_{3} \cdot 15 \mathrm{H}_{2} \mathrm{O} ; \mathrm{C}_{3} \mathrm{SSCH}_{15}\right)$ is formed in addition to ettringite as a result of the reaction between C-S-H and $\mathrm{SO}_{4}^{2-}, \mathrm{CO}_{2}$ or $\mathrm{CO}_{3}{ }^{2-}$, and water. The $\mathrm{AFt}$ phase is structurally similar to ettringite, with $\mathrm{Al}^{3+}$ substituted by $\mathrm{Si}^{4+}$. Thaumasite is more stable at lower temperatures since silicon tends to adopt the octahedral co-ordination. However, thaumasite is formed also at temperatures around $20{ }^{\circ} \mathrm{C}$ and above. ${ }^{15,16}$ Once thaumasite is formed, it remains stable up to $30{ }^{\circ} \mathrm{C} .{ }^{17}$ The formation of thaumasite always needs a source of carbonate which can be supplied from the limestone contained in the cement itself. The damage due to the thaumasite formation was investigated by various authors. ${ }^{18-21}$

Thus, the interactions of sulfate ions with the cement matrix result in a disruption of the concrete and a significant loss of the mechanical strength and mass, and it leads to a reduction of the service life of concrete composites.

This paper is focused on the sulfate attack on finegrained concrete, investigating the effect of $0.5 \%$ sulfuric acid (simulating $M I C C$ ) on the microstructural changes of various types of concrete after a treatment for the period of six months. The changes in the microstructure were determined with mercury intrusion porosimetry and scanning electron microscope. The aim of this study was to compare the resistances of various types of concrete against the sulfate attack, in view of the microstructural changes that may result in a disintegration and the subsequent loss of the concrete material.

\section{MATERIALS AND METHODS}

Fine-grained concrete specimens $(40 \mathrm{~mm} \times 40 \mathrm{~mm} \times$ $160 \mathrm{~mm}$ ) were prepared with a water-to-binder ratio of 0.45 and three fractions of quartz sand according to Czech standard CSN 72 1200, with designations PG 1 (<0.5 mm), PG $2(0.5-1 \mathrm{~mm})$ and PG $3(1-2.5 \mathrm{~mm})$, in the weight-to-binder ratio of $1: 1: 1: 1$. Seven concrete mixtures with different compositions of the binder were prepared: PC - Portland cement CEM I 42.5 R (100\%); SRP - sulfate-resisting Portland cement (100\%); SRS sulfate-resisting slag cement CEM III/B $32.5 \mathrm{~N}-\mathrm{SV}$ $(100 \%)$; MK - metakaolin (20\%), Portland cement $(80 \%)$; GL - ground limestone (20\%), Portland cement (80 \%); GBFS - granulated blast-furnace slag (20\%), Portland cement $(80 \%)$ and FA - low-calcium fly ash (20\%), Portland cement $(80 \%)$. The mixtures with the supplementary cementing materials (metakaolin, limestone, slag and fly ash) corresponded to Portland blended cements according to European standard EN 197-1. The chemical compositions and physical properties of the initial materials are given in Table 1. The specimens were unmolded $24 \mathrm{~h}$ after the casting under laboratory conditions $\left(t=(22 \pm 2){ }^{\circ} \mathrm{C}, \mathrm{R}\right.$. H. was $\left.(55 \pm 5) \%\right)$ and

Table 1: Chemical compositions and physical properties of initial materials in mass fractions, $w / \%$

Tabela 1: Kemijska sestava in fizikalne lastnosti izhodnih materialov v masnih deležih, $w / \%$

\begin{tabular}{|c|c|c|c|c|c|c|c|c|}
\hline \multicolumn{2}{|c|}{ Materials } & $\mathrm{PC}$ & SRP & SRS & MK & GL & GBFS & FA \\
\hline \multirow{13}{*}{ 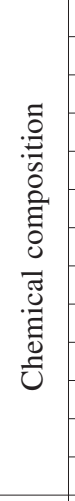 } & $\mathrm{CaO}$ & 61.48 & 60.92 & 47.53 & 0.20 & 54.73 & 34.81 & 3.60 \\
\hline & $\mathrm{SiO}_{2}$ & 21.26 & 21.88 & 32.84 & 58.70 & 0.81 & 39.78 & 53.70 \\
\hline & $\mathrm{Al}_{2} \mathrm{O}_{3}$ & 5.08 & 3.65 & 6.01 & 38.50 & 0.32 & 8.17 & 24.62 \\
\hline & $\mathrm{Fe}_{2} \mathrm{O}_{3}$ & 3.64 & 4.36 & 1.54 & 0.72 & 0.10 & 1.54 & 7.91 \\
\hline & $\mathrm{SO}_{3}$ & 2.42 & 2.39 & 2.30 & 0.02 & 0.05 & 0.46 & 0.96 \\
\hline & $\mathrm{MgO}$ & 0.86 & 3.15 & 7.21 & 0.38 & 0.38 & 13.22 & 1.67 \\
\hline & $\mathrm{Na}_{2} \mathrm{O}$ & 0.12 & 0.41 & 0.32 & 0.04 & - & - & 0.85 \\
\hline & $\mathrm{K}_{2} \mathrm{O}$ & 0.91 & 0.86 & 0.65 & 0.85 & - & - & 2.62 \\
\hline & $\mathrm{MnO}$ & 0.07 & 0.11 & 0.03 & - & 0.01 & 0.89 & - \\
\hline & $\mathrm{TiO}_{2}$ & 0.29 & 0.34 & 0.41 & 0.49 & - & 0.24 & 1.03 \\
\hline & $\mathrm{Cr}_{2} \mathrm{O}_{3}$ & - & - & - & - & - & 0.14 & - \\
\hline & $\mathrm{P}_{2} \mathrm{O}_{5}$ & - & - & - & - & - & 0.03 & 2.25 \\
\hline & L.O.I. & 4.17 & 1.97 & 0,82 & 1.67 & 43.99 & 1.48 & 2.82 \\
\hline \multirow{2}{*}{  } & $\begin{array}{c}S S A \\
\left(\mathrm{~m}^{2} \mathrm{~kg}^{-1}\right)\end{array}$ & 360 & 685 & 504 & 13060 & 390 & 384 & 340 \\
\hline & $\begin{array}{c}S G \\
\left(\mathrm{~kg} \mathrm{~m}^{-3}\right)\end{array}$ & 3120 & 2650 & 2950 & 1070 & 2700 & 2810 & 2300 \\
\hline
\end{tabular}

Note: "-" ... not tested 
placed into a water bath for another $27 \mathrm{~d}$. Afterwards, the specimens were air-dried for $24 \mathrm{~h}$ and then the pore structures of the samples were studied to determine the total porosity and the pore-size distribution with highpressure mercury intrusion porosimetry using a Micromeritics PoreSizer 9310 porosimeter, and the microstructures of samples were observed with a scanning electron microscope, MIRA3 (TESCAN), equipped with an EDX probe.

Subsequently, the test samples were covered with a protective coat to prevent drying and they were placed into a solution of $0.5 \% \mathrm{H}_{2} \mathrm{SO}_{4}$ for a period of six months. The concentration of the sulfuric acid was chosen in accordance with the literature. ${ }^{22}$ The solution level was maintained at a height of $5 \mathrm{~mm}$ and the solutions were weekly renewed. After six months, the samples were slit lengthwise and the changes in their microstructures were studied with high-pressure mercury intrusion porosimetry and scanning electron microscope. Attention was paid mainly to the lower parts of the samples, near the $\mathrm{H}_{2} \mathrm{SO}_{4}$ solution.

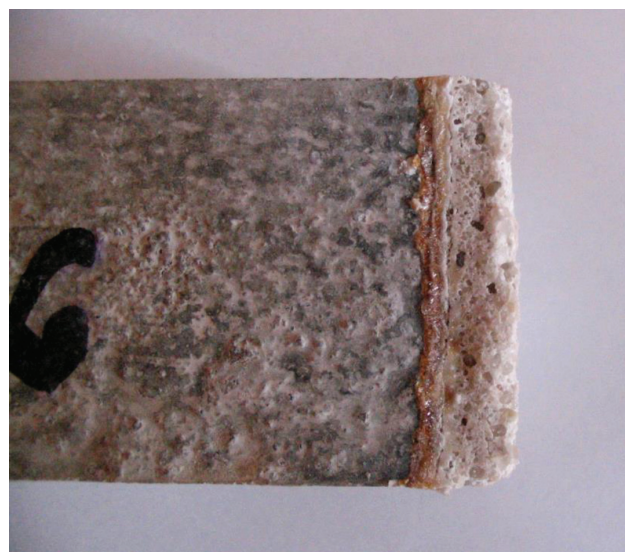

Figure 1: Lower part of SRP concrete sample after being in $\mathrm{H}_{2} \mathrm{SO}_{4}$ $0.5 \%$ for 6 months

Slika 1: Spodnji del SRP-betonskega vzorca po namakanju 6 mesecev v $\mathrm{H}_{2} \mathrm{SO}_{4} 0,5 \%$

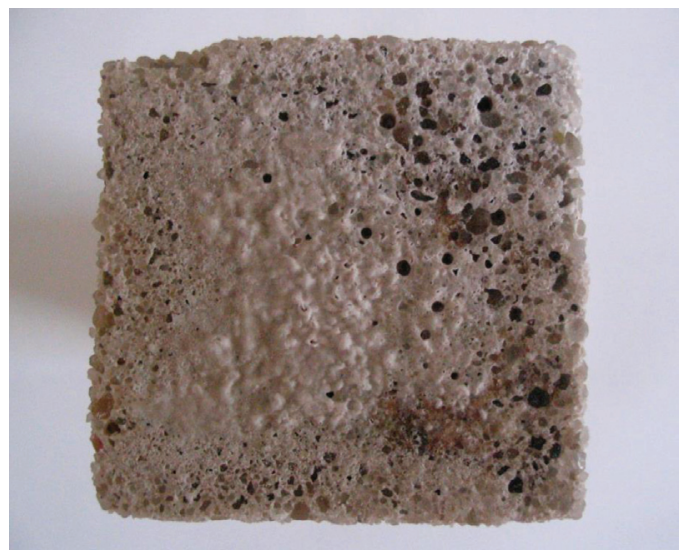

Figure 2: Immersed part of SRP concrete sample after being in $\mathrm{H}_{2} \mathrm{SO}_{4}$ $0.5 \%$ for 6 months

Slika 2: Potopljeni del SRP-betonskega vzorca po namakanju 6 mesecev $v \mathrm{H}_{2} \mathrm{SO}_{4} 0,5 \%$

\section{RESULTS AND DISCUSSION}

\subsection{Visual appearance}

After being in $0.5 \% \mathrm{H}_{2} \mathrm{SO}_{4}$ for six months, a visible degradation of the submerged part occurred on all the investigated samples and the creation of a rust layer on the periphery of each sample, just above the level of the acid, took place. Figure 1 illustrates the effect of the $0.5 \%$ sulfuric acid on the SRP-concrete sample. A detailed view of the immersed part of the sample is shown in Figure 2. There are well recognizable exposed aggregates and white precipitates of gypsum $\left(\mathrm{CaSO}_{4} 2 \mathrm{H}_{2} \mathrm{O}\right)$ on the surface.

\subsection{Changes in the porosity}

It was found that all the concrete samples had almost identical pore distributions before the sulfate attack. The samples mainly contained pores with a diameter of $0.1 \mu \mathrm{m}$ (Figure 3). The largest porosity was observed for the FA concrete and the lowest for the SRS concrete. The results of the determination of the cumulative pore volumes of the samples exposed to the sulfate attack for six months are also in Figure 3. The pore-size distribution remained approximately the same, but the samples had a slightly higher amount of the pores with a diameter below $0.1 \mu \mathrm{m}$. This means that larger pores were filled in to a certain degree by the products of the reactions of the
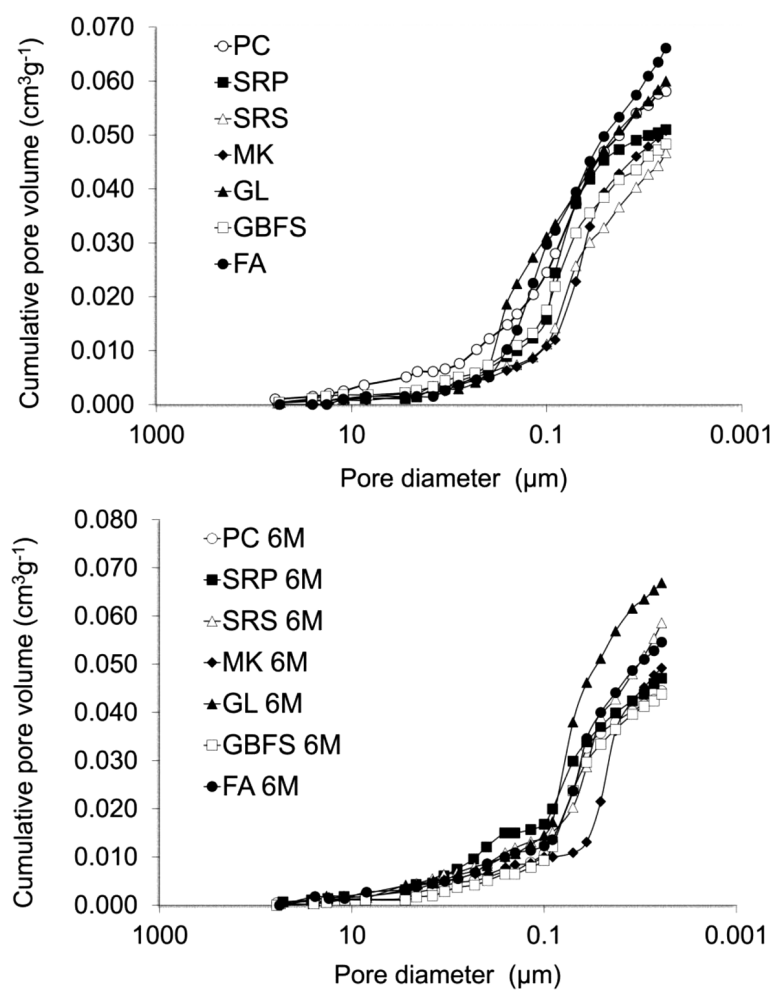

Figure 3: Pore-size distribution of the investigated concrete samples before and after a 6-month (6M) exposure to $\mathrm{H}_{2} \mathrm{SO}_{4} 0.5 \%$

Slika 3: Razporeditev velikosti por $\mathrm{v}$ preiskovanih vzorcih betona pred 6-mesečno (6M) izpostavitvijo $\mathrm{H}_{2} \mathrm{SO}_{4} 0,5 \%$ in po njej 
M. VYŠVAřIL et al.: MICROSTRUCTURAL CHANGES OF FINE-GRAINED CONCRETE ...

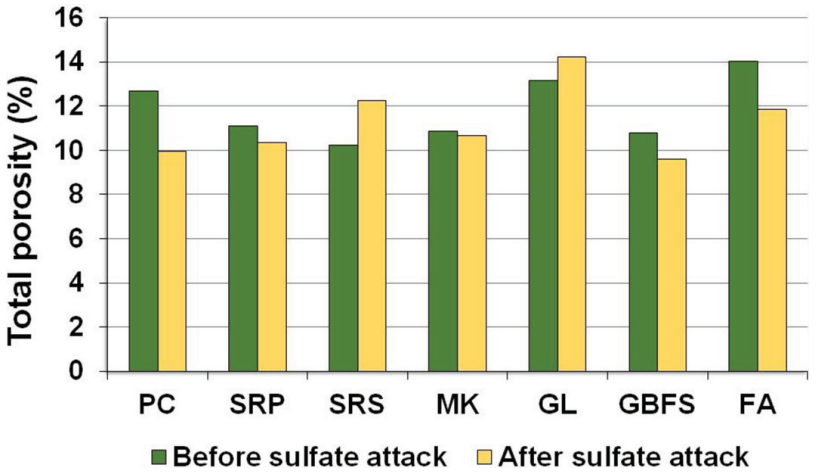

Figure 4: Total porosity of the concrete samples before and after a 6-month exposure to $0.5 \% \mathrm{H}_{2} \mathrm{SO}_{4}$

Slika 4: Skupna poroznost betonskih vzorcev pred 6-mesečno izpostavitvijo $\mathrm{H}_{2} \mathrm{SO}_{4} 0,5 \%$ in po njej

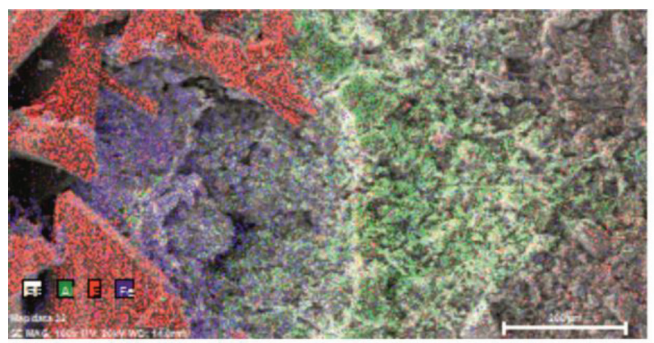

FA

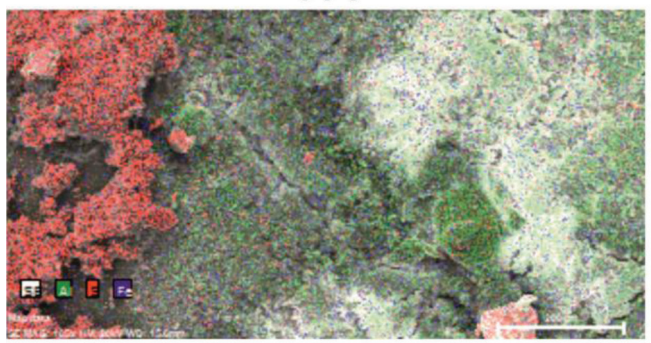

MK

sulfate attack. The total porosities of the investigated concrete samples are depicted in Figure 4. The reduction in the total porosity of most samples occurred after the sulfate attack, which indicates that the pores were filled in by the products of the sulfate corrosion of the concrete.

The most significant decrease was observed for the PC and FA concretes. Conversely, for the SRS and GL concretes, an increase in the total porosity was found. In the case of the SRS concrete, it is apparently due to the low porosity before the sulfate attack, prohibiting a smooth crystallization of the sulfate-corrosion products in the pores and a disruption of the microstructures of the samples. The increase in the total porosity of the GL concrete is in accordance with the conclusions of E. F.

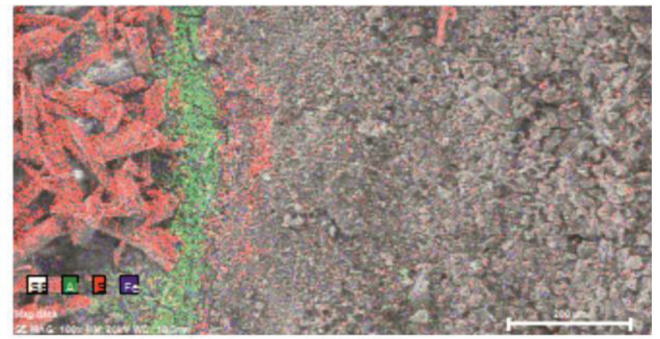

SRS

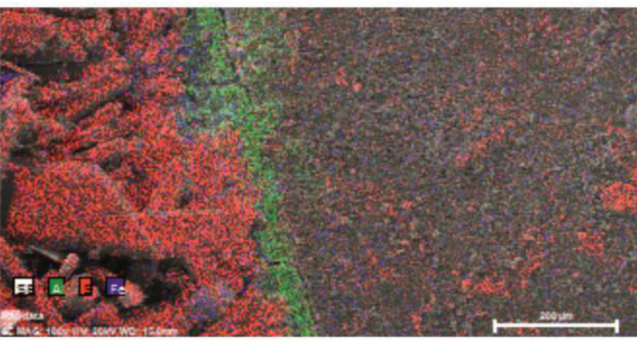

GL

Figure 5: Distribution of sulfur (red), aluminum (green) and iron (blue) on the surfaces of lower parts of lengthwise slices of the selected types of concrete samples obtained with EDX SEM

Slika 5: EDX-SEM-razporeditev žvepla (rdeče), aluminija (zeleno) in železa (modro) na površini spodnjega dela vzdolžnega prereza izbranih vrst betona

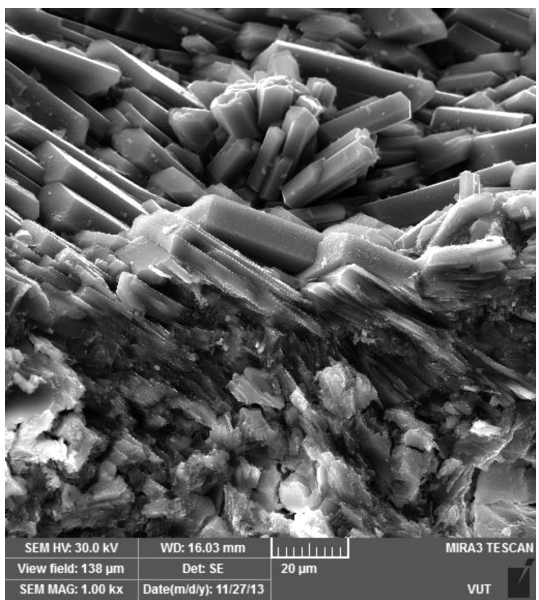

Figure 6: SEM image of gypsum identified in the structure of submerged part of PC-concrete sample after a 6-month sulfate attack Slika 6: SEM-posnetek sadre, dobljene v potopljenem delu PC-betonskega vzorca po 6-mesečni izpostavitvi sulfatu

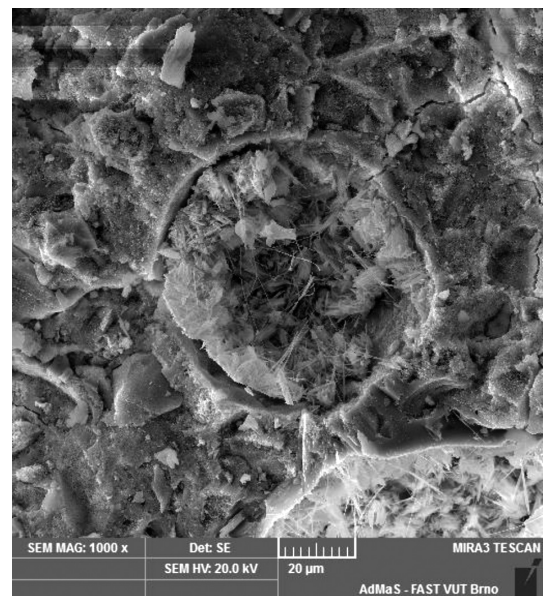

Figure 7: SEM image of microstructure of PC-concrete sample after a 6-month sulfate attack

Slika 7: SEM-posnetek mikrostrukture vzorca PC-betona po 6-mesečni izpostavitvi sulfatu 


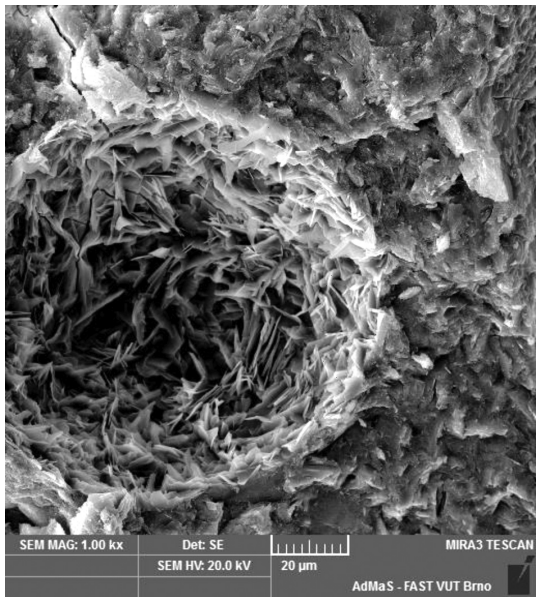

Figure 8: SEM image of microstructure of MK-concrete sample after a 6-month sulfate attack

Slika 8: SEM-posnetek mikrostrukture vzorca MK-betona po 6-mesečni izpostavitvi sulfatu

Irassar et al. ${ }^{12} \mathrm{He}$ found that a concrete containing a limestone filler is more susceptible to a sulfate attack and less durable than the corresponding plain mortar, as indicated by its larger expansion, greater surface deterioration, deeper transition zone of the attack, larger deposition of gypsum and higher degree of the $\mathrm{CH}$ depletion.

\subsection{Changes in the microstructure}

By mapping the chemical-element distribution on the surface of the lower part of the lengthwise slice of each samples, the presence of the locations rich in sulfur, iron and aluminum was determined. In the lowest parts of the samples, sulfur prevailed in the gypsum form. Using EDX REM, an aluminum-rich zone, identified as hydrated $\mathrm{Al}(\mathrm{OH})_{3}$, was located just above the gypsum. The presence of $\mathrm{Al}(\mathrm{OH})_{3}$ is presumably caused by the formation of ettringite from $\mathrm{C}_{4} \mathrm{AF}$ in the presence of gypsum

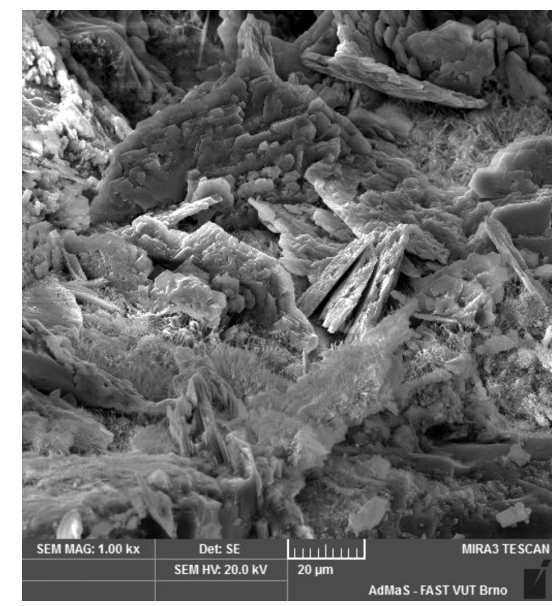

Figure 9: SEM image of microstructure of GL-concrete sample after a 6-month sulfate attack

Slika 9: SEM-posnetek mikrostrukture vzorca GL-betona po 6-mesečni izpostavitvi sulfatu

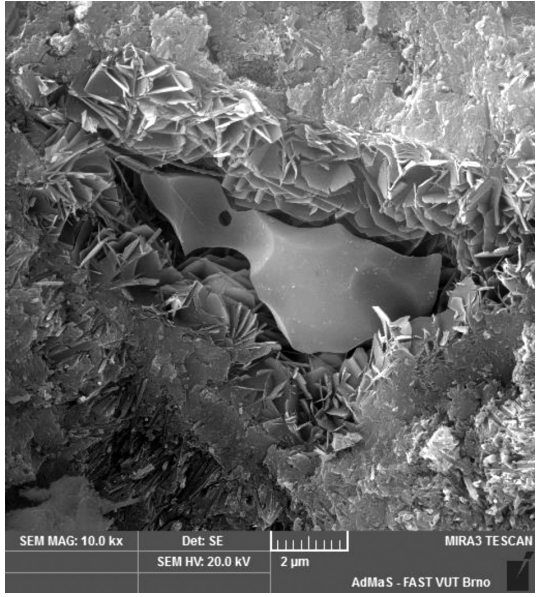

Figure 10: SEM image of microstructure of GBFS-concrete sample after a 6-month sulfate attack - detail of a partially reacted slag grain Slika 10: SEM-posnetek mikrostrukture vzorca GBFS-betona po 6-mesečni izpostavitvi sulfatu - detajl delno zreagiranega zrna žlindre

(Equation (2)). Thus, it can be concluded that even during a six-month sulfate attack, ettringite forms from $\mathrm{C}_{4} \mathrm{AF}$. In the case of the samples made from the materials with a high iron content (FA, PC, SRP), the zone rich in iron was present between the sulfur and aluminum locations. The iron compound was not sufficiently established; it is just known that it is a silicate without aluminum. The identification of this compound is still in process. Selected EDX REM images of the mapped chemical-element distributions are shown in Figure 5. The PC-, SRP- and FA-concrete samples had very similar distributions of chemical elements, and so did SRS and GBFS. The MK sample did not have a narrow zone rich in aluminum because of a high aluminum content in the used metakaolin.

In the submerged parts of all the investigated samples, typical prismatic gypsum crystals were identified with EDX SEM (Figure 6). The pores of the PC-concrete sample were largely filled with the crystalline

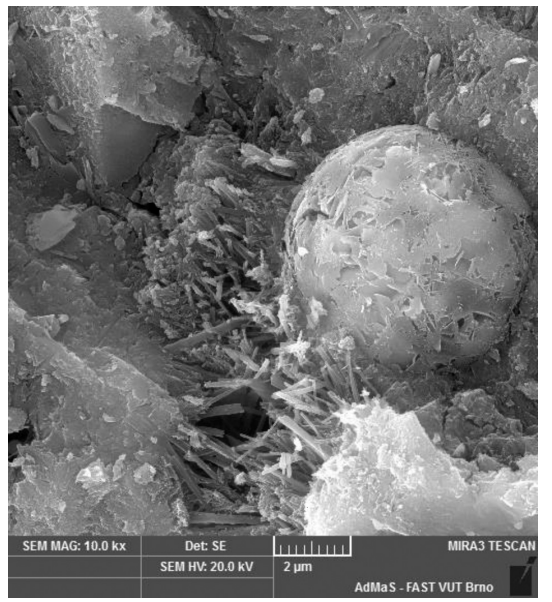

Figure 11: SEM image of microstructure of FA-concrete sample after a 6-month sulfate attack

Slika 11: SEM-posnetek mikrostrukture vzorca FA-betona po 6-mesečni izpostavitvi sulfatu 
products of the sulfate attack, particularly with the typical needle crystals of ettringite (Figure 7), confirming the reduction in the total porosity. Of all the investigated concrete samples, the SRP- and SRS-concrete samples showed the smallest changes in the microstructures as just small amounts of ettringite were identified.

In the microstructures of the MK- and GL-concrete samples, a lot of portlandite in typical hexagonal crystals was identified on the surfaces of the pores (Figures 8 and 9), in contrast to the microstructures of these samples before the sulfate attack. An increased amount of portlandite in the pores was observed in all the studied samples, but for the MK and GL samples, this amount was enormous. This increased presence of portlandite was probably caused by the capillary action of the solution while the samples were kept in $\mathrm{H}_{2} \mathrm{SO}_{4}$. A direct contact of the cement matrix with the solution of sulfuric acid leads to a sulfate attack and the formation of gypsum. The non-aggressive solution penetrates to the higher parts of a sample, dissolves the surrounding $\mathrm{Ca}(\mathrm{OH})_{2}$ and, during the drying of the sample, its crystallization occurs in the pores. For this reason, in the lowest parts of the samples, only gypsum as the primary product of the sulfate attack was identified. In addition to gypsum, the higher parts of the samples also contained ettringite and other by-products of the sulfate attack. In the case of the GBFS-concrete sample, crystals of portlandite were concentrated in the crevices around the partially reacted slag grains (Figure 10). Ettringite was identified on the surfaces of the pores. The FA-concrete sample contained a lot of damaged particles of fly ash and needle crystals of ettringite (Figure 11).

\section{CONCLUSIONS}

Microstructural changes in various types of finegrained concrete after a six-month sulfate attack were investigated with mercury intrusion porosimetry and scanning electron microscopy. It was found that the total porosity of most samples was decreased after the sulfate attack, indicated by the products of the sulfate corrosion filling in the pores of the concrete. The most significant decrease was observed for the PC and FA concretes. The smallest changes in the microstructure occurred in the samples made from the sulfate-resisting cements. Thereby, the suitability of their use in the case of a sulfate attack was confirmed. The formation of the locations rich in sulfur, iron and aluminum during the sulfate attack on the concrete was determined by mapping the chemical-element distribution. Due to the presence of $\mathrm{Al}(\mathrm{OH})_{3}$, which was identified in the aluminum-rich location, it can be concluded that, even during a sixmonth sulfate attack, ettringite is formed from $\mathrm{C}_{4} \mathrm{AF}$. The fate of the iron originating from $\mathrm{C}_{4} \mathrm{AF}$ is still not clear.

\section{Acknowledgement}

This outcome was achieved with the financial support of the Czech Science Foundation (grant no. 13-22899P) and the European Union "Operational Programme Research and Development for Innovations", No. CZ.1.05/ 2.1.00/03.0097 (AdMaS).

\section{REFERENCES}

${ }^{1}$ A. Neville, Cem. Concr. Res., 24 (2004), 1275-1296, doi:10.1016/ j.cemconres.2004.04.004

${ }^{2}$ H. Yuan, P. Dangla, P. Chatellier, T. Chaussadent, Cem. Concr. Res., 53 (2013), 267-277, doi:10.1016/j.cemconres.2013.08.002

${ }^{3}$ D. Stein, Instandhaltung von Kanalisationen, $3^{\text {rd }}$ ed., Ernst, Berlin 1999, 141

${ }^{4}$ J. Skalny, J. Marchand, I. Odler, Sulfate attack on concrete, $1^{\text {st }}$ ed., Spon Press, London 2002

${ }^{5}$ H. F. W. Taylor, R. S. Gollop, Mechansisms of chemical degradation of cement-based systems, $1^{\text {st }}$ ed., E \& FN Spon, London 1997, 177-184

${ }^{6}$ P. J. Monteiro, K. E. Kurtis, Cem. Concr. Res., 33 (2003), 987-993, doi:10.1016/S0008-8846(02)01097-9

${ }^{7}$ R. P. Khatari, V. Sirivivatnanon, Cem. Concr. Com., 27 (1997), 1179-1189, doi:10.1016/S0008-8846(97)00119-1

${ }^{8}$ H. F. W. Taylor, Cement Chemistry, 1st ed., Thomas Telford, London 1997, doi:10.1680/cc25929

${ }^{9}$ B. Lothenbach, E. Wieland, Waste Management, 26 (2006), 706-719 doi:10.1016/j.wasman.2006.01.023

${ }^{10}$ R. Gollop, H. F. W. Taylor, Cem. Concr. Res., 26 (1996), 1013-1028, doi:10.1016/0008-8846(96)00089-0

${ }^{11}$ R. Gollop, H. F. W. Taylor, Cem. Concr. Res., 22 (1992), 1027-1038, doi:10.1016/0008-8846(92)90033-R

${ }^{12}$ E. F. Irassar, V. L. Bonavetti, M. Gonzalez, Cem. Concr. Res., 33 (2003), 31-41, doi:10.1016/S0008-8846(02)00914-6

${ }^{13}$ J. Marchand, E. Samson, Y. Maltais, J. J. Beaudoin, Cem. Concr. Com., 24 (2002), 317-329, doi:10.1016/S0958-9465(01)00083-X

${ }^{14}$ M. Santhanam, M. D. Cohen, J. Olek, Cem. Concr. Res., 31 (2001), 845-851, doi:10.1016/S0008-8846(01)00510-5

${ }^{15}$ S. Diamond, Cem. Concr. Com., 25 (2003), 1161-1164, doi:10.1016/ S0958-9465(03)00138-0

${ }^{16}$ M. Collepardi, Cem. Concr. Com., 21 (1999), 147-154, doi:10.1016/ S0958-9465(98)00044-4

${ }^{17}$ D. Macphee, S. J. Barnett, Cem. Concr. Res., 34 (2004), 1591-1598, doi:10.1016/j.cemconres.2004.02.022

${ }^{18}$ N. J. Crammond, Cem. Concr. Res., 15 (1985), 1039-1050, doi:10.1016/0008-8846(85)90095-X

${ }^{19}$ G. R. Gouda, D. M. Roy, A. Sarkar, Cem. Concr. Res., 5 (1975), 519-522, doi:10.1016/0008-8846(75)90026-5

${ }^{20}$ M. Romer, Cem. Concr. Com., 25 (2003), 1173-1176, doi:10.1016/ S0958-9465(03)00155-0

${ }^{21}$ M. Romer, L. Holzer, M. Pfiffner, Cem. Concr. Com., 25 (2003), 1111-1117, doi:10.1016/S0958-9465(03)00141-0

${ }^{22}$ N. De Belie, J. Montenya, A. Beeldensb, E. Vinckec, D. Van Gemertb, W. Verstraetec, Cem. Concr. Res., 34 (2004), 2223-2236, doi:10.1016/j.cemconres.2004.02.015 